\title{
Migration THROUGH GAELIC AND RUSSIAN PROVERBS
}

\section{MARIA KOROLEVA}

'All I ask, the heaven above And the road below me.' R.L.S. "Why to travel far away, while it's good at home to stay," A Russian Proverb

\section{Introduction ${ }^{1}$}

A framework that cuts across disciplines is a characteristic feature of modern research process. The present comparative research based largely on Scottish Gaelic and Russian material was carried out especially for the Celto-Slavica forum as a part of a long-term project of constructing a Corpus of Proverbs on Demographic Issues.

A proverb reflects different aspects of social and economic life of people and forms a perfect subject for demographic research due to a number of its specific qualities. It voices various aspects of prevalent public opinion; presents solutions based on collective experience; serves as a representative model of behaviour of a person within a society; may also serve as a unique source when the required data is lacking. Besides, such characteristics as its conciseness and capaciousness allow to promptly analyse a bulk of material concerning various issues, such as migration, for example. No other folk genre rivals proverb in its observation and objectivity.

The aim of the paper is to reveal what is seen of migration through Gaelic and Russian proverbs and how does it fit into the wider international proverbial context. Since a proverb crystallises the most common of human judgements and experiences, it is no wonder that the same proverb can be encountered in many different languages and essentially provide the same opinions.

\section{Sources and methodology}

From a bulk of more than 4,000 of original Gaelic, 50,000 of Russian and more than 40,000 proverbs collected in different regions of Europe, Asia and Africa, about 90 Gaelic, 180 Russian and 300 other proverbs $^{2}$ on

\footnotetext{
${ }^{1}$ The author acknowledges assistance and advice received from Arseniy Sinitsa in the preparation of the selection of Russian proverbs used throughout this paper.

${ }^{2}$ For selection of appropriate comparanda see Abbreviations section below.
} 
migration were selected for our research, then carefully analysed and compared by the author.

It is obvious that the Russian sources on average provide a huge bulk of such material, since the Russians can boast having the unsurpassed collection of proverbs by Vladimir Dahl, the largest and the richest in the world, and other large collections, while for Scottish Gaelic one obtains far less extensive sources, relying mainly upon the material compiled by Alexander Nicolson. ${ }^{3}$ To eliminate these differences the Gaelic and Russian proverbs are compared within a wider international context of proverbial lore.

The general methodology for selection and comparison and rationale for using non-demographic data for demographic purposes was amply described in the previous research on proverb as a subject for socio-demographic research (Koroleva \& Sinitsa 2008).

\section{Migration as defined by proverbs}

History reminds us that Scots have always been notorious for their migration to other countries of the world, frequently a forced one, for the lack of space or constant trouble at home, they even got the name 'a nation of emigrants' (Devine 2004: 1-25). Many a good Gaelic name left its trace in the history of Europe and Americas, as well as Australia, indeed even in Russia every single Scottish clan name happen to be somehow mentioned in her history. ${ }^{4}$ The Russians, on the contrary, at least until the twentieth century, were rather reluctant to leave their motherland, for in case of trouble there was plenty of room for them to move to.

So, how do these two peoples so different in their migration behaviour, the Gaels and the Russians, perceive the migration process? The proverbs give no single answer to that question.

The international proverbs say migration is a complex issue of sublime nature. First, it is a cognition process, a way to find out about the world one lives in, a way to know a man and oneself: A man is known while on the move (PE: 207), ${ }^{5}$ but any travel implies throes compared to those of dying: Road throes are death throes (PE: 572), not an easy way

\footnotetext{
${ }^{3}$ Though if we look at the amount of Gaelic proverbs on migration in relation to the bulk of all Gaelic proverbs, it will be more numerous than the same ratio for the Russian material, which indicates that the issue of migration was of more importance for the Gaelic Scotland, which corresponds well with historic data.

${ }^{4}$ The research to prove the fact was undertaken by D. Fedosov, O. Nozdrin and P. Dukes (University of Aberdeen) and will be available in a forthcoming prosopography publication.

${ }_{5}^{5}$ All the given examples of international proverbs were translated by the author.
} 
of cognition. The second answer is even more philosophic in nature, proverbs say our whole life is migration to destination unknown, the world is just a hotel, we all pass and go: World is an inn, those who come are to depart (TP: 38). No line is drawn between those departed on a trip and those dead, both lose all their social links: Those who died or went away have no friends (TP: 78). It is interesting the way the movement of population is viewed, what the demographers separate into spatial (migration) and natural (birth, marriage, death) movement is interwoven in human experience into one constant process.

Russian proverbs firmly stand within the general proverbial context $(10,13,34,43,59,60,70,78,91,105,151,159) .{ }^{6}$ While on the road you get to know a man and the world better $(86,159,176)$, travelling is shown as a very difficult undertaking $(28,29,157,161,171)$ and one is even allowed to break some religious principles while away from home $(42,95)$. Birth and death, or the natural movement, is also established in terms of travel (147), and there is a comparison drawn between a travelling man and a dead one (46). ${ }^{7}$ The Gaelic proverbs tend to differ in the latter where a man on the move and a dead man are contrasted rather than compared $(233)^{8}$ which slightly stands out of the general context, but the rest follows the world tradition $(185,196,197,207,208,219,234,240,252,253,264$, 266).

\section{Native vs foreign}

The majority of international proverbs bring to the surface the binary opposition of native vs foreign land. They claim that one's native land is the best place to live in: Homeland is mother, foreign land is stepmother (PE: 346), one cannot live without one or s/he may lose his most impressive part, or, in terms of modern cultural approach, his or her own identity: A man without homeland is a nightingale without its song (PE: 495), the voluntary rejection of native land eventually leads to solitude and complete seclusion: He that forsakes his motherland dies a lonely man (SP: 90). Exile or forced migration has always been amongst

\footnotetext{
${ }^{6}$ Parentheses contain the numbered Russian and Gaelic examples for which we refer the reader to the Appendix.

${ }^{7}$ This notion was so deeply rooted in the Russian culture that we find M.V. Lomonosov talking about emigrants to Poland and other foreign parts as zhivyye pokoyniki or "live deadmen" (Lomonosov 1952: 401).

${ }^{8}$ Though if we look at the tradition of keening in Ireland, those who migrated were lamented as if they were dying, it is a rough guess the same tradition existed in Gaelic Scotland, though I was not able to find any reference to that. The Scottish Gaelic language, however, is active in employing such image, in many areas (e.g. Islay) the verb employed when expressing the concept of 'dying' is siubhal (lit. 'travelling') (Grannd 2000: 15, 76).
} 
punishments for most serious crimes in many cultures and seldom was it voluntary.

In Russian and Gaelic proverbs alike, this opposition is perfectly clear. The Russian proverbs show the natural relation of a person to his native place $(3,5,6,11,12,32,33,35,36,38,51,61,64,66,71,74,80$, $82,93,101,107,118,122,123,125,128,129,132,142-144,148,154$, $172,177,179)$ and the loss of identity in a foreign land $(75,88,158,164)$. The Gaelic proverbs bring together the land and the people that live there $(183,201,204,231,235,236,243,246,251,256)$, and the idea of identity is closely connected with the idea of one's language (198).

\section{Pro et contra migration}

\subsection{Adventurous or conservative?}

But there exists a group of international proverbs which say one's homeland is any place where life is easy: Where it's best for me, there's home for me (SP: 190). This attitude, encouraging migration, is closely linked in the popular opinion with envy for things that seem better at a distance (248). Other proverbs warn that at a closer look life in a foreign land will turn out very difficult: He who lives in a foreign land is like a loaded donkey or a bridled horse (PE: 43) and nothing awaits a man once he gets to that country: There's gold promised in a strange land, you come and see not even copper there (PE: 572). There is also a series of such proverbs aimed at preventing people from migration.

It is worth noting that, though there exist - well within the international context - a series of Russian proverbs saying any place where life is easy is good enough to live in $(50,152,178)$, we find no proverb of the kind in Gaeic sources.

In Russian culture the amount of proverbs warning that life abroad is harder $(7-9,14,37,48,54,56,89,102-104,106,116,126,139,140$, $141,174)$ well overweighs the opposite ones $(4,39,40,44,58,65,73,76$, $84,100,117,124,137,138,146,150,163,168)$. These two 'voices' - we will call them conservative and adventurous - are distinct for the Gaelic proverbial lore (the adventurous one being louder in Scotland than in Russia $(182,222,224,238,239,248,257,259,261))$, the conservative voice prevailing though $(181,186,228,230,237)$.

\subsection{Qualities that help to migrate}

Still that conservative voice did not stop all the migrants for obvious reasons. And many proverbs from all over the world bring out some peculiar features that one is required to obtain when moving places. The most widespread requirements are cautious actions: Finding $a$ bride and finding a new dwelling site needs caution (SP: 102); one has to be really 
persistent or be ready to wait (187); and ask many questions: Ask and you'll get to Kars (PE: 338).

Russian proverbs list the following features one needs to exhibit while migrating or travelling: unsleeping vigilance (110), foresight and forethought $(30,45,57,92,109162)$, persistance $(53,63)$ and trust in God $(94,96)$. In Gaelic ones $(220,249)$ the features are different: prudence $(184,255)$, patience (187), caution (188), modesty (217), common sense $(194,242)$ and determination $(189,232)$, which is more in accord with the world lore.

\subsection{Homesickness}

While in a foreign land a man starts to experience homesickness which may last for one's whole life: Lose a friend and you'll cry for seven years, leave your motherland and you'll cry for the rest of your life (PE: 490), it is true even if the new land is sweet: Though sweet is the foreign land, a man will always be homesick (PE: 482).

One finds such proverbs in Russia and those of great lyrical force $(41,47,67-69,72,77,79,120)$, proverbs found in Gaelic editions are not that straightforward $(193,198,258)$.

\subsection{Choice or no choice}

One's native land is generally seen through proverbs as a goldmine in every sense: Native land is a land of gold! (PE: 440). And to stay is a more decent decision than to migrate for a richer life: Better being a shoe sole in one's native land than a sultan in a foreign land (UP: 98).

Russian material provides a bouquet of proverbs stating that to stay at home is a better choice $(15,16,31,81,83,99,108,119,127,130,133$, 136), Gaelic proverbs do not raise the question of choice at all, which is true for many Gaels who never made a choice for themselves while leaving the place but were forced to. ${ }^{9}$

\section{Socially approved reasons for migration}

Despite widespread negative attitude to migration on the whole there are still several reasons to migrate which are socially justified and approved in any culture, i.e. marriage, paying a visit, travel for travel's sake

\footnotetext{
${ }^{9}$ This raises the issue of forced migration and exile, which is too complex a question to deal with in this brief paper, but it is curious to note how the Gaelic language treats it. While a student at SMO on the Isle of Skye, the author was taught three terms, the explanation and usage of which was a great surprise: for people moving inside the country - imrich ('migration'), for forced migration - fuadach ('clearance'), for migration upon free will, emigration inclusive, - eilthireachd ('exile'). That implies that one migrates only while inside the country, but if you leave it at will, it will still be called an exile in Gaelic!
} 
(modernist cultural and educational tourism), labour migration and pilgrimage.

\subsection{Marriage and visiting}

\subsubsection{Marriage}

First, let us have a look at marriage. The selected international proverbs denounce matrilocal unions: Three follies: to mount a mountain and smoke, to start a journey when it's dark, to leave one's native home to live in a wife's house (KP: 253); it seems wiser for a man to bring his wife from a distant place, the farther the better: Take a horse from a nearby place, take your wife from afar (UP: 73). In order to do that one has to go a long way, but, surprisingly, the road in this case seems short and easy: $A$ thousand ri will be as one to a man in love (PE: 619).

Russian proverbs don't denounce matrilocal unions, they also advice upon one's wife coming not from afar (112). Gaelic proverbs in their majority are in favour of finding a wife from the neighbourhood as well $(215,260,262,263,265)$.

\subsubsection{Paying a visit}

Within the world tradition such unions brought guests, usually the relatives on the wife's side: Guests come from the place you took your wife (PE: 563); Kinship ties are kept by legs (PE: 593). No visits meant weaker social links: Far from eyesight - far from heart (PE: 55), it appeared that a neighbour was considered closer than any relative in this case, due to a shorter distance and ready ability to help: Better $a$ neighbour nearby than a relative far away (PE: 46).

Russian proverbs on visiting and keeping up the kinship ties are scanty (134), neighbour's help is more appreciated (55). Gaelic proverbs follow the same pattern $(225,241,244,245)$.

\subsection{3. 'Hospitality Club'}

Hospitality is perhaps a universal law found in all proverbs of the world. Many would claim this duty is sacred: A guest is God's guest (KP: 12). Nevertheless, the patience of the host is not endless and the proverbs say it ends in two or three days: Even the eldest brother won't receive the best of treatment after three days (PE: 126). If one is on the move he should go on and lose no time sitting in comfort as a guest: A traveller should be walking (PE: 39).

Russian proverbs say a guest is pleasing to a host $(17,18,23,24,27$, 98, 165). In Gaelic culture hospitality may go to an extreme as here: $I$ would give him a night's quarters though he had a man's head under his 
arm, and the general lore shows an especial chivalrous attitude to guests $(191,202,205,206,212,213,226,227,229,254,265)$.

\subsubsection{Insolent guest}

There is an equal share of international proverbs showing that despite the law of hospitality people are not ready to spend their resources (time, food or shelter) on each and every stranger: If you stick a sheep every time a guest comes there will be nothing left of the flock (PE: 247). Perhaps, some of them doubt if they get their own back some day as the proverb promises: We to strangers, and strangers to us (DMGP: 51). Or, perhaps, they have met with a special kind of an insolent guest: He ate plenty, he drank much and insisted on a night's quarters (PE: 131). But to treat even an insolent guest in that manner is to ruin one's reputation forever: Old man departed and sin remained, guest left and shame remained (PE: 613).

Both Russian (19-22, 25, 26, 49, 121, 166) and Gaelic proverbs $(192,195,203,209,223,247)$ are familiar with the above-mentioned insolent guest type.

\subsection{Travel for education}

Second, let us explore travel or tourism. The traditional culture pays great respect to any learned man, the knowledge does not necessarily come with age but with experience and travel: He knows more who travelled farther not who lived longer (PE: 81). The proverbs thus show that travel was a great investment into human capital.

There is only one Russian proverb which indeed says that knowledge does not necessarily come with age (62), and no Gaelic proverb was found at all to correspond to this group of international proverbs.

\subsection{Pilgrimage}

Third comes pilgrimage. Strangely enough, the proverbs from different corners of the world reflect dubious attitude towards pilgrims, perhaps because of diverse fake pilgrims: Pretending to be a pilgrim, to put in root and to vomit with rats (PE: 403), the pilgrimage in proverbs is often a dream but anyone is free to have or to fulfill it: Even a cripple dares to dream of Jerusalem (PE: 44).

Again, as in case with travel for education, here we find only a couple of proverbs in Russian $(87,160,169)$, and not a single one in Gaelic. 


\subsection{Labour migration}

Fourth is labour migration (military and missionary inclusive). The world proverbial lore proves that regional occupation or temporary work was regular and people used to return to their families during the festive season: A strange land is the best place to make money, home is best to celebrate the New Year (PE: 282). The adaptation to city life is shown as a slow process: It's quick to put on city cloths, but it takes time to become a citisen (SP: 179).

The Russian proverbs reveal a strong opposition between city vs village $(1,2,85,90,97,111,113-115131,135,145,149,153,155,156$, $167,170,173)$, the Gaelic ones show more of the traditional occupations, such as fishing $(180,190,199,200,210,211,214,218,250)$.

\section{Connection between migration and life-expectancy}

Finally, it should be noted, that a connection between life-expectancy and migration is curiously estimated, and this could be seen only in Gaelic proverbs, both Scottish and Irish, there is no Russian proverb on the matter out of the whole selected lot. The proverb has it that: A man lives long in his native place (ABCP: 35), but: Remove an old man from his native place, and he will leave you his skin (DSP: 29).

\section{Conclusions}

'A proverb cannot be contradicted', they say, it is a collective experience just too firmly rooted in our mind. Proverbs allow a novel look at migration, they remind the demographers that people tend to perceive things by employing binary oppositions. As a result there is no "native" without "foreign". And those two "voices" are always there - the conservative one, connecting one to the past, and the adventurous one, which is active in exploring the yet unknown future possibilities. The proverbs grouped that way allow us to consider the problem of migration in a way different to the usual demographic approach - that is in all its complex duality.

Proverbs embrace the majority of migration-related questions; in this paper, I was able to describe just two or three general issues, but there are many more specific themes which would cover almost any situation. Only several specific problems the selected proverbs face not, for example 'brain drain'.

The comparison of Russian and Gaelic material shown as two distinct strands within the general fabric of the international proverbial lore provides the answers to the questions asked in the very beginning of the paper: the majority of migration patterns we know from Russian and Scottish history are well reflected in the proverbs, exposing a lot of the 
national character and identity along with the general reflections, while the international context exposed the points of similar migration behaviour and attitudes which unexpectedly proved to be more alike than different.

The general wisdom of all proverbs is quite simple and easy to follow: a man should not migrate at all. If one wants to live a happy, long and fruitful life, he should stay in his native land, at home. In wider philosophical sense migration is viewed as something inevitable, all the people are migrants on the Earth. But here too, proverbs look at the bright side. Though inevitable and our destination we know not, any movement is a great opportunity for cognition and development, they claim; and this is, perhaps, the greatest wisdom passed on to us from the generations of our ancestors. The adventurous voice proves stronger in the end.

Lomonosov Moscow State University, Moscow, Russia

\begin{abstract}
Abbreviations
ABCP - O'Donnel, J., 1996, The Appletree Book of Celtic Proverbs in Irish and English, Belfast: Appletree Press.

DMGP - Negris, A., 1831, A Dictionary of Modern Greek Proverbs, with an English translation, explanatory remarks, and philological illustrations, Edinburgh: Thomas Clark.

DSP - Collins, J., 1823, A Dictionary of Spanish Proverbs, compiled from the best authorities in the Spanish Language, translated into English; with explanatory illustrations from the Latin, Spanish, and English authors, London: S. Brooke.

KP - Dzhalil, O., \& Dzhalil, Dzh., 1972, The Kurdish Proverbs and Sayings in Kurdish and Russian (In Russian: Kurdskiye poslovitsy $i$ pogovorki na kurdskom i russkom yazykakh), Moscow: Nauka.

PE - Braginskiy, I. S., 1961, Proverbs and Sayings of the Peoples of the East (In Russian: Poslotitsy i pogovorki narodov Vostoka), Moscow: Izdatel'stvo vostochnoy literatury.

SP - Kapchitsa, G. L., ed. \& trans., 2009, Somali Proverbs and Sayings: in Somali and Russian, with the Russian Equivalents (In Russian: Somaliyskiye poslovitsy i pogovorki: Na somaliyskom i russkom yazykakh s russkimi sootvetstviyami), Moscow: Librokom.

TP - Mansurova, O. Yu., 2005, The Turkish-Russian Dictionary of Proverbs: 1111 sayings taken from everyday speech (In Russian:
\end{abstract}


Turetsko-russkiy slovar' poslovits: 1111 izrecheniy, ispol'zuemykh $v$ povsednevnom obshchenii), Moscow: AST Vostok-Zapad.

UP - Khamraev, M.K., 1981, The Uyghur Proverbs and Sayings. In the Uyghur and Russian languages with the Russian Parallels (In Russian: Uygurskiye poslovitsy i pogovorki. Na uygurskom i russkom yazykakh is russkimi parallelyami), Moscow: Glavnaya redactsiya vostochnoy literatury izdatel'stva "Nauka", 1981.

\section{References}

Devine, T. M., 2004, Scotland's Empire 1600-1815, London.

Dahl, V. I., 1879, Proverbs of the Russian Nation (In Russian: Poslovitsy russkogo naroda), vol. 1, St. Petersburg, Moscow.

Grannd, S., 2000, The Gaelic of Islay: A Comparative Study, Aberdeen.

Illyustrov, I. I., 1904, A Collection of Russian Proverbs (In Russian: Sbornik rossiyskikh poslovits $i$ pogovorok), Kiyev: Tipografia S.V. Kul'zhenko.

Koroleva, M. V. \& Sinitsa, A. L., 2008, 'Proverbs on Child-rearing Expenses as a Subject of Socio-demographic Research' (In Russian: 'Poslovitsy o raskhodakh na detey kak predmet sotsial'nodemograficheskogo issledovaniya'), in: Denisenko, M., Troitskaya, I., eds., Istoricheskaya demografiya, Moscow: MAKS Press.

Lomonosov, M. V., 1952, 'On Preservation and multiplication of the Russian Nation' (In Russian: 'O sokhranenii i razmnozhenii rossiyskogo naroda', in: id., Polnoye sobraniye sochineniy, 1950-1983, vol. 6. (Trudy po russkoy istorii, obschestvenno-ekonomicheskim voprosam i geografii 1747-1765 gg. M. L. Izd-vo AN SSSR), 381-403.

MacGillivray, A., 1928, Our Gaelic Proverbs. A Mirror of the Past, Glasgow.

Nicolson, A., 2003, A Collection of Gaelic Proverbs and Familiar Phrases, Edinburgh.

Snegirev, I.M., 1999, Russian Proverbs and Parables (In Russian: Russkiye narodnyye poslovitsy i pritchi), Moscow: Indrik. 


\section{Appendix}

\section{A List of Russian Proverbs on Migration ${ }^{10}$}

1. "A calf in the city is wiser than an acolyte in the countryside," Gorodskoye telya mudreney derevenskogo ponomarya (Dahl 1879: 403). 2. "A city is like a kingdom, but a village is a paradise," Gorod - tsarstvo, a derevnya - ray (Dahl 1879: 403).

3."A cuckoo cuckoos, over her homeless fate she broods," Kukushka kukuyet, po bezdom'yu goryuyet (O tom kukushka i kukuyet, chto svoyego gnezda net $)^{11}$ (Dahl 1879: 401).

4. "A falcon lingers not in one place, when it sees a bird it follows it," Sokol na odnom meste ne sidit, a gde ptitsu vidit, tuda i letit (Dahl 1879: 403).

5."A foreign land is kept by praise, but ours stands firmer from ill speech," Chuzhaya storonushka nakhvalom zhivyot, a nasha haykoyu stoit (Dahl 1879: 400).

6. "A foreign land is a stepmother," Chuzhaya storona - machekha (Dahl 1879: 402).

7."A foreign land is a thief (a robber)," Chuzhaya storona - vor (razboynik) (Dahl 1879: 402).

8. "A foreign land isn't swayed by tears," Chuzhbina slezam ne verit (Dahl 1879: 402).

9."A foreign land isn't sweet," Chuzhbina ne potachliva (Dahl 1879: 402). 10. "A foreign land makes a man wise," Chuzhaya storona pribavit uma (Dahl 1879: 402).

11. "A foreign land rubs a man up the wrong way," Chuzhbinka ne po shersti gladit (Dahl 1879: 402).

12. "A foreign land will make even a crow from your parts your very best friend," Na chuzhoy storonushke rad svoyey voronushke (Dahl 1879: 401). 13. "A foreign land will teach a misfortunate lad (will torture and teach)," Nauchit goryuna chuzhaya storona ( $i$ vymuchit $i$ vyuchit) (Dahl 1879: 402).

14. "A foreign place is a wild wood," Chuzhaya storona - dremuch bor (Dahl 1879: 402).

15. "A foreign place is highly praised (by a matchmaker) but she herself will never set her foot there," Chuzhuyu storonu khvalit (svakha), a sama ni nogoy (a sama tuda ni po nogu) (Dahl 1879: 401).

\footnotetext{
${ }^{10}$ Compiled by A. Sinitsa. Translation and footnotes by M. Koroleva.

${ }^{11}$ The explanations and variants given in parentheses were supplied by Vladimir Dahl to his original edition.
} 
16. "A foreign-foreigner will praise his foreign land and we'll keep listening while on polaty ${ }^{12}$ we lie," Khvalit chuzh-chuzhenin chuzhu storonu, a my slushayem, na polatyakh lezhuchi (Dahl 1879: 400).

17. "A good guest makes the host pleased," Gost' dobroy vsegda khozyainu priyaten (Snegirev 1999: 85).

18. "A guest came to stay, and a host feels happy and gay," Gost' prishel, hozyainu khorosho (Snegirev 1999: 85).

19. "A guest has come and a trouble has come," Gost' na dvor - i beda na dvor (Snegirev 1999: 85).

20. "A guest hasn't come, God delivered from harm," Gost' ne prishel, Bog ubytka izbavil (Snegirev 1999: 85).

21. "A guest is small until he has eaten all," Gost' potuda mal, poka ne poyedal (Snegirev 1999: 85).

22. "A guest stays not long but sees a lot," Gost' nemnogo gostit, da mnogo vidit (Snegirev 1999: 85).

23. "A guest that came unasked is better than the asked one," Nezvan gost' luchshe zvanogo (Snegirev 1999: 186).

24. "A guest that comes in time brings no waste," Ko vremyu gost' ne v ubytok (Snegirev 1999: 134).

25. "A guest who gets up early, wants to stay overnight," Gost' koli rano podymayetsya, tot nochevat' khochet (Kotoryy gost' rano podymayetsya, tot nochevat' khochet) (Snegirev 1999: 139).

26. "A guest will stay, and hurry his way," Gost' pogostit, da i domoy pospeshit (Snegirev 1999: 85).

27. "A hard choice: the guest is dear and a fast day is right here," Gost' dorogoy, a den' serednoy ${ }^{13}$ (Snegirev 1999: 85).

28. "A man who never went to sea knows not, what it means to pray, and pray a lot," Kto v more ne byval, tot dosyta Bogu ne malivalsya (Dahl 1879: 332).

29. "A man who never went to sea, a sorrow has never seen," Kto v more ne byval, tot gorya ne vidal (Dahl 1879: 332).

30. "A man who step on road dares should take his $l a p t i^{14}$, all five pairs," V dorogu idti - pyatery lapti spliesti (Dahl 1879: 330).

31. "A matchmaker doesn't come with the truth," Svat s pravdoy ne ezdit (Illustrov 1904: 102).

32. "A native land is a mother, a foreign land is a stepmother," Rodimaya storona-mat', chuzhaya-machekha (Dahl 1879: 402).

\footnotetext{
${ }^{12}$ Russian polati is a traditional plank bed in a cosy place between the hot Russian pechka and a thick wooden wall.

${ }^{13}$ Wednesday (den' serednoy) according to the Orthodox practice is a fasting day.

${ }^{14}$ Lapti (pl) are a traditional footwear made of bast.
} 
33. "A native land will stroke you gently, a foreign land will stroke you the wrong way," Svoya storona po sherstke gladit,chuzhaya nasuprotiv (Dahl 1879: 402).

34. "A pechka $a^{15}$ pampers, a road teaches," Pechka drochit (nezhit), a dorozhka uchit (Dahl 1879: 330).

35. "A pine has grown far from it's own forest, but keeps waving to it (singing to it, talking to it)," Daleko sosna stoit, a svoyemu lesu veyet (shumit, govorit) (Dahl 1879: 403).

36. "A pine is fine in the soil where it has grown," Gde sosna vzrosla, tam ona i krasna (Dahl 1879: 403).

37. "A place which isn't far away, but still is so sad to stay," Storonushka i ne dal'nyaya, da pechal'naya (Dahl 1879: 402).

38. "A place you were born in, there you'll fit in," Gde kto roditsya, tam $i$ prigoditsya (Chto gde roditsya, to tam i goditsya. Chto gde rozhdaetsya, to tam i prigozhdayetsya.) (Dahl 1879: 401).

39. "A settled stone gathers moss," Na odnom meste i kamen'mokhom obrastayet (Dahl 1879: 403).

40. "A sly sparrow, though at home he sits, gathers no compliments," Vor vorobey domosed, a lyudi ne khvalyat (Dahl 1879: 405).

41. "A stable stops not a steed of the Steppes," Stepnogo konya na konyushne ne uderzhish' (Dahl 1879: 402).

42. "A traveller may fast not," Putniku posty razresheny (Dahl 1879: 330). 43. "A visit pays back," K nam lyudi ezdyat - $k$ sebe v gosti zovut (Dahl 1879: 404).

44. "A wild goose has flown to Rus ${ }^{16}$ here he'll stay and then fly away," Priletel gus' na Rus' - pogostit da uletit (Dahl 1879: 405).

45. "A wise companion halves the road," Umnyi tovarishch - polovina dorogi $i^{17}$ (Dahl 1879: 330).

46. "Abroad to stay is like in a casket to be lain (it's lonely and silent there)," Na chuzhbinke - slovno v domovinke (i odinoko, i nemo) (Dahl 1879: 402).

47. "Afonyushka ${ }^{18}$ feels sad in a foreign land," Skuchno Afonyushke na chuzhoy storonushke (Dahl 1879: 401).

\footnotetext{
${ }^{15}$ A Russian oven used for cooking, heating and sleeping on its top in winter.

${ }^{16}$ Rus' is a poetic and historic word for Russia. It is interesting to note, that the Gaelic name for Russia - an Ruis - seems almost identical to this older name where in both cases the final " $\mathrm{s}$ " is palatalized, but in Gaelic it would change the quality of the sound while in Russian it remains just soft.

${ }^{17}$ Compare: "Two shorten the road" (Ir.).

${ }^{18}$ Afonyushka is a familiar name to call Afanasiy. Afanasiy is the Russian form of Athanasios, a Greek name meaning "immortal".
} 
48. "All the world is home for a lonely man," Odinokomu - vezde dom (Dahl 1879: 405).

49. "An insolent guest likes to stay long," Gost' besstuzh posidet' lyubit (Snegirev 1999: 85).

50. "Any place is good enough, when your belly is full enough," Gde ni zhit', tol'ko by sytu byt' (Dahl 1879: 405).

51. "As it is at home, so it is at Don," Kakovo na domu, takovo i na Donu (Dahl 1879: 401).

52. "Ask a fine lad woo for you, and the girl will see him too; there'll be no guilty part if she gives away her heart," Molodtsu sebya ne spryatat', bude poshliut devku svatat'; a polyubit devka svata - nikomu ne vinovata (Illustrov 1904: 102).

53. "Ask and you'll get as far as Kiev," ${ }^{19}$ Yazyk do Kieva dovedet (Snegirev 1999: 294; Dahl 1879: 330).

54. "At home everything is quick and easy, in a foreign land everything turns out bad," Doma vse sporo, a v chuzhe zhit'e khuzhe (Dahl 1879: 401).

55. "Better a neigbour at hand than a kinsman far away," Blizhniy sosed luchshe dal'ney rodni (Snegirev 1999: 392).

56. "Boast not when you are leaving home, boast on your return home," Ne khvalis' ot"yezdom, khvalis' priyezdom (Dahl 1879: 333).

57. "Bread won't make your bag too heavy," Khleb v puti ne $v$ tyagost' (Dahl 1879: 330).

58. "Brew, do sour on kvass $^{20}$ that is your own!" Kisni, opara, na svoyem kvasu! (Dahl 1879: 403).

59. "Charity is half the road to God: fasting leads you to the gates of Heaven, and the charity opens them," Milostynya - polovina dorogi $k$ Bogu: post vedet $k$ vratam raya, a milostynya otvoryayet ikh (Snegirev 1999: 404).

60. "Charity on earth is food for a long journey," Milostynya - sukhari na dal'nyuyu dorogu (Snegirev 1999: 303).

61. "Don, Don, ${ }^{21}$ but it's better at home," Don, Don, a luchshe dom (Dahl 1879: 401).

62. "Don't ask the aged, ask the experienced," Ne sprashivay u starogo, sprashivay u byvalogo (Snegirev 1999: 193).

\footnotetext{
${ }^{19}$ In folk literature, Kiev was represented as a famous city in Russia (present day Ukraine). The proverb means: ask and you'll find anything.

${ }^{20}$ Kvass is a fermented beverage made from black or regular rye bread; it is enjoyed in almost all corners of Russia.

${ }^{21}$ Don is a big river in the south of Russia. In folk and literary works it often stood for the idea of Freedom.
} 
63. "Don't seek for the way, ask," Ne ishchut dorogi, a sprashivayut (Dahl 1879: 330).

64. "Even a beggar keeps his clobber dear," Lyubit i nishchiy svoye khlamovishche (Dahl 1879: 401).

65. "Even a crane flies to seek warm lands," I zhuravl' tepla ishchet (Dahl 1879: 404).

66. "Even a crow (a doggie) from your land looks sweet," $S$ rodnoy storonki i vorona (i sobachka) mila (Dahl 1879: 401).

67. "Even a dog knows its corner," I sobaka svoyu storonu znayet (Dahl 1879: 403).

68. "Even a dog likes its own corner," Svoya storonushka i sobake mila (Dahl 1879: 403).

69. "Even a dog misses its home," Na chuzhbine i sobaka toskuyet (Dahl 1879: 402).

70. "Even a father is a roadmate to his son," $V$ doroge $i$ otets synu tovarishch (Dahl 1879: 330).

71. "Even a handful of earth from your native land is dear to the heart," Svoya zemlya i v gorsti mila (Dahl 1879: 401).

72. "Even a horse longs to run back to its native land, even a dog gnaws its leash to return," I kon' na svoyu storonu rvetsya, a sobaka otgryzetsya da uydet (Dahl 1879: 402).

73. "Even a snipe saw foreign lands," I kulik chuzhu storonu znayet (Dahl 1879: 404).

74. "Even a wee pebble is dear in a native land," Na rodnoy storone $i$ kameshek znakom (Dahl 1879: 401).

75. "Even a wormwood won't grow without any root," Bez kornya $i$ polyn' ne rastet (Dahl 1879: 401).

76. "Even beyond the mountains there are people," I za gorami lyudi (Dahl 1879: 404).

77. "Even bread misses the land it grew in," 22 I khleb po svoyey storone skuchayet (Dahl 1879: 401).

78. "Even one's own father becomes a roadmate (should help)," V doroge i rodnoy otets tovarishch (dolzhen pomogat') (Dahl 1879: 330).

79. "Even the bones weep for their motherland," ${ }^{23}$ I kosti po rodine plachut (Dahl 1879: 401).

80. "Even the Penza $a^{24}$ guests were happy to discover their own crow in Moscow," I penzentsy v Moskve svoyu voronu uznali (Dahl 1879: 401).

\footnotetext{
${ }^{22}$ Vladimir Dahl explains that the imported bread gets spoiled.

${ }^{23}$ Vladimir Dahl refers to the belief that weeping and howling of the bones could be heard from some graves.

${ }^{24}$ Penza is a city that stands on the banks of the river Sura.
} 
81. "Every bird praises its own nest," Vsyakaya ptitsa svoye gnezdo khvalit (Snegirev 1999: 68).

82. "Every pine sings for its own wood (speaks to its own forest)," Vsyakaya sosna svoyemu boru shumit (svoyemu lesu vest' podayet) (Dahl 1879: 403).

83. "Every snipe praises its own bog," Vsyak kulik svoye boloto khvalit (Dahl 1879: 401).

84. "Fare thee well, my Mother Rus', it's the warmth I now choose," 25 Proshchay, matushka Rus': ya k teplu potyanus' (Dahl 1879: 404).

85. "Find anything in Moscow but pigeon's milk, father and mother," $V$ Moskve tol'ko net ptich'yego moloka, da ottsa i materi (Snegirev 1999: 72).

86. "Find yourself under a host's roof sleeping, and you'll see where yours is leaking," Poka pod chuzhoy kryshey ne pobyvayesh', svoya, gde techet, ne uznayesh' (Dahl 1879: 404).

87. "First in Sudogda fast, then in Suzdal pray, and to Yuriyev you come for a merry day," $V$ Sudogde postit'sya, v Suzdale molit'sya, $v$ Yur'yeve poveselit'sya (Snegirev 1999: 298).

88. "Follow the custom of the people you live with," $V$ kakom narode zhivesh', togo i obych 'ya derzhis' (Dahl 1879: 400).

89. "For a man who leads a lonely life, a roof is where he finds bread," Odinkú - gde khleb, tam i ugol (Dahl 1879: 405).

90. "For some Moscow is like mother, and for some it's like stepmother," Moskva-komu mat', komu machekha (Dahl 1879: 410).

91. "From overseas with the news, from the backyard with the guests," Iz zamorya s vest'mi, a iz zadvorya s gost'mi (Snegirev 1999: 124).

92. 'Go for a day, take bread for a week," Yedesh' na den' - khleba beri na nedelyu (Dahl 1879: 330).

93. "God is gracious to you in your homeland too," Miluyet Bog i na svoyey storone (Dahl 1879: 400).

94. "God shows the right ways," Bog puti kazhet (Dahl 1879: 330).

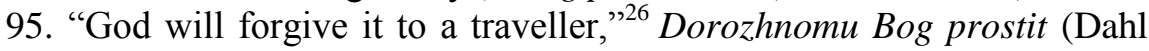
1879: 330).

96. "God will guide you on the way you need," Nuzhnyy put' Bog pravit (Dahl 1879: 330).

97. "He is staying on Don, left his wife at home alone," Zhivet na Donu, ostavya doma zhenu (Snegirev 1999: 109).

98. "He let me eat, he let me drink, he let me sleep," Napoil, nakormil $i$ spat' ulozhil (Dahl, 2: 365). ${ }^{27}$

\footnotetext{
${ }^{25}$ These words are meant to be said by a crane ready to fly away, Vladimir Dahl explains.

${ }^{26}$ If a person is not keeping his or her religious fasting.

${ }^{27}$ Compare 254.
} 
99. "He that keeps praising a foreign land to a friend, but sets no foot upon its soil," Khvalit drugu chuzhuyu storonu, a sam v neyo ni po nogu (Snegirev 1999: 267).

100. "He who seeks distinction, fame, shouldn't at one place remain," Kto khochet iskat' chesti, tot ne zhivi na odnom meste (Snegirev 1999: 146).

101. "In a foreign land even the slightest help is a gift of God (anything is a gift of God)," Na chuzhbinke - i to Bozhiy dar (vse Bozhiy dar) (Dahl 1879: 402).

102. "In a foreign place even a child is your foe," Na chuzhoy storone $i$ rebenok vorog (Dahl 1879: 402).

103. "In a foreign place even Spring loses its grace," Na chuzhoy storone i vesna ne krasna (Dahl 1879: 402).

104. "In a foreign place like in a forest," $V$ chuzhom meste, chto $v$ lesu (Dahl 1879: 402).

105. "In a game and on the road men are known," $V$ igre da $v$ poput'ye lyudey uznayut (Dahl 1879: 330).

106. "In a new place they will teach you some good sense," Na storone obtolkut boka (Dahl 1879: 402).

107. "In foreign parts even an old hag is sent by God," Na chuzhoy storone i starushka Bozhiy dar (Dahl 1879: 402).

108. "Keep praising overseas while on the pechka you sit," Khvali zamor'ye, na pechi sidyuchi (Snegirev 1999: 578).

109. "Leave your home concerns at home," Domashnyaya duma $v$ dorogu ne goditsya (Dahl 1879: 330).

110. "Let your arm and leg sleep while at home, but keep your head awake while on the road," Doma ruka i noga spit, $v$ doroge $i$ golovushka ne dremli (Dahl 1879: 330).

111. "Live in a village and see no merriment," Zhit'v derevne - ne vidat" vesel'ya (Dahl 1879: 403).

112. "Marry not the praised girl that's far away, choose the simple one that's nearest to stay!" Ne beri dal'nyuyu khválenku, beri blizhnyuyu khayanku! (Dahl 1879: 404).

113. "More honour dying far away than on a woman's lap to stay," Luchshe umirat' $v$ pole, chem $v$ bab'yem podole (Dahl 1879: 321).

114. "Moscow is a kingdom, but our village is a paradise," Moskva tsarstvo, a nasha derevnya - ray (Dahl 1879: 403).

115. "Moscow is good to stay, but still not like home," Khorosha Moskva, da ne doma (Dahl 1879: 403).

116. "No comfort for a stranger but a joke," Chuzhoy chelovek ne na utekhu, na prosmekh (Dahl 1879: 402). 
117. "No man is a prophet in his own country," V svoyey zemle nikto prorokom ne byvayet (ne byval) (Dahl 1879: 405).

118. "No need to travel far away to find it's good at home to stay," Nezachem daleko, i zdes' khorosho (Dahl 1879: 400).

119. "No one can praise foreign parts so well but a matchmaker," Chuzhuyu storonu nikto protiv svakhi ne nakhvalit (Illustrov 1904: 102).

120. "No relatives left, but the heart can't forget its native place," Rodnykh net, a po rodimoy storonke serdtse noyet (Dahl 1879: 402).

121. "Not like mother, not like father, but rather like a stranger, a nameless ranger," Ni v mat', ni v ottsa, a v proyezzhego molodtsa (Snegirev 1999: 198).

122. "Not much food (at home) but the bed is good," Khot' ne uyedno (doma), tak ulezhno (Dahl 1879: 400).

123. "On fathers' land you firmly stand and better die than leave this land!" S rodnoy (roditel'skoy) zemli - umri, ne skhodi! (Dahl 1879: 403).

124. "On the other side of the river they can live as well," I za rekoy lyudi zhivut (Dahl 1879: 404).

125. "On the road I go, tears do flow; remember my dears and burst into tears," Vyydu na put' - slezki tekut'; vspomnyu svoikh - i toshno po nikh (Dahl 1879: 401).

126. "Once upon a time there lived a fine lad, he saw no happiness in his native village, but as he left it, he burst into tears," Zhil-byl molodets; $v$ svoyey derevne ne vidal vesel'ya, na chuzhbinu vyshel - zaplakal (Dahl 1879: 402).

127. "One sharp match-maker keeps praising a foreign place (but she herself at home does sit)," Odna svakha chuzhu storonu nakhvalivayet (a sama doma sidit) (Dahl 1879: 401).

128. "One's own custom is always dearer," Svoy byt mileye (Dahl 1879: 401).

129. "One's own place is the dearest," Vsyakomu mila svoya storona (Dahl 1879: 401).

130. "Only unworthy bird will soil its nest," Khudaya ta ptitsa, kotoraya gnezdo svoye marayet (Dahl 1879: 401).

131. "Out to Moscow you set, nothing but money to get," V Moskvu idtit' - tol'ko den' 'gu dobyt' (Dahl 1879: 410).

132. "Overseas is warmer but here it's merrier," Za morem tepleye, a u nas svetleye (veseleye) (Dahl 1879: 400).

133. "Praise the land beyond the sea, but stay at home!" Khvali zamor'ye (chuzhuyu storonu), a sidi doma! (Snegirev 1999: 578; Dahl 1879: 400).

134. "Rare to see, dearer to be," Rezhe vidish' - mileye budesh' (Snegirev 1999: 232). 
135. "Seek your fortune far from home but love the place where you were born," Ishchi dobra na storone, a dom lyubi po starine (Dahl 1879: 405).

136. "Silly is the bird that isn't pleased with its nest," Glupa ta ptitsa, kotoroy gnezdo svoye nemilo (Dahl 1879: 401).

137. "Sit and sour like mead!" Sidi, kak med kisni! (Dahl 1879: 403).

138. "Sit at home and get nothing," Doma sidet' - nichego ne vysidet' (Dahl 1879: 403).

139. "Tamburines are held in high repute across the mountains, but when they reach us they are like lukoshkos ${ }^{28}$," Slavny bubny za gorami, a k nam pridut, chto lukoshko (Dahl 1879: 400).

140. "Tears will not pay in Moscow," Moskva slezam ne verit (ne

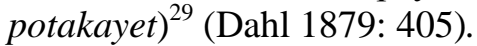

141. "The first time you move (to a new place) is like fighting out half a fire, the second time you move is like fighting out the whole fire," Odin raz (Odnova) perevozit'sya (domom) - polpozhara vystoyat'; dva raza (dvoyu) perevozit'sya - ves' pozhar vystoyat' (Dahl 1879: 333).

142. "The millstones say: it's better in Kiev to stay, the mortar answers: like here, like there," Zhernova govoryat: $v$ Kieve luchshe, a stupa govorit: chto tut, chto tam (Dahl 1879: 401).

143. "The place where you were taken out of your mother's belly (i.e. motherland) is the dearest (the place you will never forget)," Mila ta storona (ne zabudesh' tu storonu), gde pupok rezan (t.e. rodina) (Dahl 1879: 400).

144. "The sea is for the fishes, the sky is for the birds, the motherland is the circle of universe for the men," Rybam more, ptitsam vozdukh, a cheloveku otchizna vselennoy krug (Snegirev 1999: 231).

145. "The town has its point, everywhere there is an eating-joint or a creep-joint," Gorod zateynyy: chto ni shag, to s"yestnoy da piteynyy (Dahl 1879: 403).

146. "The water that runs not, gets spoilt," Stoyachaya voda gniyet (kisnet) (Dahl 1879: 333).

147. "There is only one road to the afterworld," Mertvym na tot svet otovsyudu doroga odna (Snegirev 1999: 303).

148. "There's merry life beyond the sea, but not ours, and here's all grief, but our own," Za morem vesel'ye, da chuzhoye, a u nas i gore, da svoye (Dahl 1879: 400).

149. "They don't thresh rye on Moscow land, for city on the bog does stand, but still they eat more than in the countryside," Moskva stoit na

\footnotetext{
${ }^{28}$ Russian lukoshko is a traditional bast basket, here the proverb hints at tamburines being of a very low quality.

${ }^{29}$ Dahl explains that if you are a stranger, people will not be sympathetic to you.
} 
bolote, rzhi v ney ne molotyat, a bol'she derevenskogo edyat (Snegirev 1999: 165).

150. "They flew overseas as geese, they returned as no swans," ${ }^{, 30}$ Poleteli zá morie gusi, prileteli tozh ne lebedi (Dahl 1879: 405).

151. "This world is home for all the people," Sey svet dom vsekh lyudey (Snegirev 1999: 235).

152. "Though in the Golden Horde, but rich," Hot'v Orde, da v dobre (tol'ko by v dobre) (Dahl 1879: 405).

153. "Though mushrooms grow in the countryside they are known in towns too," Griby rastut v derevne, a ikh $i$ v gorode znayut (Dahl 1879: 403).

154. "Though Paris is so nice to stay, Kurmysh ${ }^{31}$ is decent anyway," Khorosh Parizh, a zhivet i Kurmysh (Dahl 1879: 401).

155. "To be in heavy debt on Don, and nothing but a wife for pawn," Dolgovat' na Donu, zakladyvat' pridetsya zhenu (Snegirev 1999: 397).

156. "To earn for poll-tax you leave home, to eat bread you return," Podushnoye na storone, a khleb dóma (ishchi) (Dahl 1879: 405).

157. "To go by sea all night and day, 's like with a widow to stay," Vodoyu plyvuchi, chto so vdovoyu zhivuchi (Dahl 1879: 332).

158. "To live in a place means to follow its ways," Gde zhit', tem i slyt' (Dahl 1879: 400).

159. "To see others, to show oneself," Liudey (Na liudey) poglyadet' $i$ sebya pokazat' (Dahl 1879: 404).

160. "To Suzdal and Murom you come to pray, to Vyazniki for merry time and in Shuya for a drink you stay," V Suzdale i Murome Bogu pomolit'sya, v Vyaznikakh pogulyat', v Shuye napit'sya (Snegirev 1999: $74)$.

161. "To travel by sea as if by land," Po moryu, yako po sukhu ${ }^{32}$ (Dahl 1879: 331).

162. "Travel alone and the road is longer," Odnomu ekhat' - $i$ doroga dolga (Dahl 1879: 330).

163. "Water never flows under settled stones," Pod lezhach kamen' $i$ voda ne techet (Dahl 1879: 333).

164. "Wear the hat of the people you join," V kakoy narod pridesh', taku i shapku nadenesh' (Dahl 1879: 400).

\footnotetext{
${ }^{30}$ Vladimir Dahl adds they did not return worse by any means.

${ }^{31}$ Kurmysh used to be a centre of trade, a busy town in pre-revolutionary Nizhegorodskiy Governorate, but then gradually lost its influence and became an ordinary out-of-the-way place.

${ }^{32}$ Vladimir Dahl adds that about the dirty road they would change the saying to: "To travel by land as if by sea".
} 
165. "Welcome the guest, welcome his horse," Gostyam stol, a konyam stolb (Snegirev 1999: 85).

166. "When a visit is rare a guest is pleasant," Redkoye svidan'ye priyatnyy gost' (Snegirev 1999: 232).

167. "When you run into a debt, Volga is the place your earnings to get," Kogda nechem zaplatit' dolgu, ekhat' budet na Volgu (Snegirev 1999: 135).

168. "Whichever place you are to stay you'll serve the same tzar anyway," Gde ni zhit', a odnomu tsaryu sluzhit' (Dahl 1879: 403).

169. "While in a monastery follow its rules, ${ }^{, 33}$ V chuzhoy monastyr' so svoim ustavom ne khodyat (Snegirev 1999: 75).

170. "While in a town you eat - pay whole rouble for each wee bit, and you'll fast get into debt for each larger meal you ate," $V$ gorode kus khvatish' - rubl' platish', a dosyta nayesh'sya, $i$ ne razdelayeshsya (Snegirev 1999: 71).

171. "While on the road, even your foe you'll call: "my father!"," $V$ doroge $i$ voroga nazovesh' rodnym ottsom (Dahl 1879: 330).

172. "Why to travel far away, while it's good at home to stay," Zachem daleko, i zdes' khorosho (Dahl 1879: 400).

173. "Without money come to a city (to a marketplace) is like being an enemy to yourself," Bez deneg $v$ gorod (na torg), sam sebe vorog (Snegirev 1999: 47; Dahl 1879: 403).

174. "Woe to him who knows not a language of the land he came to," Gore v chuzhoy zemle bezyazykomu (Dahl 1879: 402).

175. "Woo yourself and ask no one, be it Fedul or Foma," Nevestu dostavay soboyu, a ne Fedulom da Fomoyu (Illustrov 1904: 101).

176. "Worth not in town, worth not on the road, worth not in a village," Ni v gorode poruka, ni v doroge tovarishch, ni v derevne sosed (Snegirev 1999: 198).

177. "You won't miss a place you know nothing about," Chego ne znayesh', tuda i ne tyanet (Dahl 1879: 401).

178. "Your mother land is not where your mother bore you, but a real paradise is where it's good to stay," Ne tam rodina, gde mat' rodila; a tam ray, gde dobryy kray (Snegirev 1999: 194).

179. "Your own land, your own dust," Svoya zemlya - svoy prakh (Dahl 1879: 401).

\footnotetext{
${ }^{33}$ A visitor must follow all the host's regulations and customs and must not interfere with other people's affairs, the nearest equivalent is: "When (while) in Rome, do as the Romans do".
} 


\section{A List of Scottish Gaelic Proverbs on Migration}

180. A chur a ruith na cuthaig, "Sending him to chase the cuckoo" 34 (Nicolson 2003: 4).

181. A h-uile cù air a' chù choimheach, "All the dogs down on the strange dog" (Nicolson 2003: 5).

182. A' chùil a bhios fosgailte, thèid na coin innte, "The dogs will go into the corner that's open" (Nicolson 2003: 4).

183. A' cur a' bhodaich às a thaigh fhèin, "Putting the old man out of his own house" (Nicolson 2003: 4).

184. Air fhad 's ge 'n tèid thu mach, na toir droch sgeul dhachaigh ort fhèin, "However far you go abroad, bring home no ill tale of yourself" (Nicolson 2003: 8).

185. Aithghearr an tàilleir dhuibh do Ghleann Cuaich, mun cuairt an saoghal, "The black tailor's short cut to Glen Quoich - round the world" (Nicolson 2003: 9).

186. Aitneachadh bò badhail, no failt' a' chruidh, "The wandering cow's welcome, or the kine's salute"

187. Am fear a bhios fad' aig an aiseag, gheibh e thairis uaireigin, "He that waits long at the ferry will get over some time" (Nicolson 2003: 13).

188. Am fear a cheanglas, 's e shiùbhlas, "He that ties best travels best" $^{\text {"36 }}$ (Nicolson 2003: 14).

189. Am fear a dh'imich an cruinne, cha d'fhiosraich co-dhiù b'fheàrr luathas no maille; ach thug e 'n $t$-urram do dh'fhear na moch-èirigh, "He who went round the globe couldn't tell which was best, speed or slowness; but he gave the palm to the early riser" (Nicolson 2003: 14).

190. Am fear a thèid don taigh mhòr gun ghnothach, bheir e gnothach às (Am fear nach toir gnothach a-mach, bheir e gnothach dhachaigh. Am fear nach toir gnothach don bhaile mhòr, bheir e gnothach às), "He that goes without business to the great house will get something there to do" (Nicolson 2003: 19).

191. Am fear a thig anmoch Disathairne 's a dh'fhalbhas moch Diluain b'fheàrr leam airson a chuideachaidh an duine sin a dh'fhuireach bhuam, "Who comes late on Saturday night and early on Monday goes away, for any help I get from him, I'd rather like him at home to stay" (Nicolson 2003: 19).

192. Am fear a thig gun chuireadh, suidhidh e gun iarraidh, "He that comes unbidden will sit down unasked" (Nicolson 2003: 19).

\footnotetext{
${ }^{34}$ Literally, a gowk's errand (All the commentaries to the Gaelic proverbs are from their Scottish editions).

${ }^{35}$ When a strange beast joins a herd, the rest attack it.

${ }^{36}$ He that fastens his knapsack or bundle most carefully will go with least interruption.
} 
193. Am fear as fhaide chaidh on taigh, 's e 'n ceòl bu bhinne chual' e riamh 'Tiugainn dachaigh', "To him that farthest went away the sweetest music he ever heard was 'Come home"" 37 (Nicolson 2003: 17).

194. Am fear as fhaide chaidh riamh on taigh, bha cho fad' aige ri tighinn dachaigh, "The man that went farthest from home had as far to come back" (Nicolson 2003: 17).

195. Am fear nach eil math air aoigheachd na h-oidhche thoirt seachad, tha e math air saodachadh an rathaid, "He that is not good at giving a bed is good at showing the road" (Nicolson 2003: 23).

196. Am fear nach treabh aig a' bhaile, cha treabh e às, "He that won't plough at home won't plough abroad" (Nicolson 2003: 25).

197. An cleachdadh a bhios aig duine staigh, bidh e aig' air chèilidh, "As his habits are at home, so they are with strangers" (Nicolson 2003: 28).

198. An cnocan, an crocan,' ars a' chailleach gu leòdach, 'far an do chaill mi mo Ghàidhlig, "s nach d'fhuair mi mo Bheurla, "The hillock, the hillock,' said the old woman, lisping, 'where I lost my Gaelic, and didn't find my English." "'38 (Nicolson 2003: 29).

199. An uair a bhios an sgadan mu thuath, bidh Murchadh Ruadh mu dheas, "When the herring is in the north, Red Murdoch is in the south",39 (Nicolson 2003: 42).

200. An uair a bhios càch air an eathar, bidh siubhal nan taighean aig Loiream, "While the rest are with the boat, Trifler goes from house to house" ${ }^{40}$ (Nicolson 2003: 41).

201. An uair a thrèigeas na dùthchasaich Ìle, beannachd le sìth Alba! "When the natives forsake Islay, farewell the peace of Scotland!" (Nicolson 2003: 46).

202. Beannachd a shaoid 's a shiubhail leis! Biodh e nochd far an robhe raoir, "The blessing of his state and his journey be with him! Let him be tonight where he was last night" $"$ (Nicolson 2003: 56).

203. Beannachd Chaluim Ghobha: 'Mo thogair ged nach till', "Smith Malcolm's blessing: 'I care not if he come not back"' (Nicolson 2003: 56).

\footnotetext{
${ }^{37}$ East or West, home is best. (Eng.) East or West, hame is best. (Scot.) Ost und West, daheim das Best. (Germ.) Oost, West, t'huis best. (Dutch.) Casa mia, casa mia, per piccina que tu sia, tu mi sembri una badia./ Casa mia, mamma mia. (Ital.)

${ }^{38}$ No man had a keener appreciaton of the absurd conceit which leads some weak-minded Celts to affect ignorance of their mother-tongue a few months' absence in the Lowlands, from which they bring home a kind of English so fine as to be unintelligible.

${ }^{39}$ The restless, unlucky man.

${ }^{40}$ This is a Lewis saying applied to contemptible fellows who stay at home while proper men go hazarding their lives at sea.

${ }^{41}$ This is like an Oriental expression of hospitality.
} 
204. Beus na tuath far am bitear, is e a nitear, "The manners of the folk one lives among will be followed"42 (Nicolson 2003: 58).

205. Bha doras Fhinn don ànrach fial, "Fingal's door was free to the needy" (Nicolson 2003: 61).

206. Bheirinn cuid oidhche dh aged a bhiodh ceann fir fo achlais, "I would give him a night's quarters though he had a man's head under his arm" (Nicolson 2003: 65).

207. Bidh dùil ri fear-fairge, ach cha bhi ri fear-reilige, "There is hope of the man at sea, but none of the man in the churchyard" (Nicolson 2003: $70)$.

208. Bidh dùil ri fear-feachda, ach cha bhi ri fear-lice, "The man of war may return, but not the buried man" (Nicolson 2003: 71).

209. Ceilidh nam ban Slèibhteach, "The visiting of Sleat women" 43 (Nicolson 2003: 87).

210. Cha bhi dùthchas aig mnaoi no aig sagart, "Women and priests have no birth-tie" (Nicolson 2003: 91).

211. Cha bhi saoithreach gun siubhal, "The industrious must be on the move" (Nicolson 2003: 93).

212. Cha chreach $e$ dùthaich, "He won't ruin the countryside" 44 (Nicolson 2003: 98).

213. Cha chumar taigh le beul dùinte, "House with closed door can't be kept" $^{45}$ (Nicolson 2003: 100).

214. Cha duine glic a thèid tric don bhaile mhòr, "He is not a wise man who goes often to the city" (Nicolson 2003: 111).

215. Cha tèid pòsadh thar muir, "Marriage goes not beyond sea" (Nicolson 2003: 141).

216. Chaidh tu gu Dùn Bheagain orm, "You went to the extreme with me" (Nicolson 2003: 148).

217. Chan eil àit' am bi meall nach bi fasgadh mu bhonn, "Wherever a height is, there is shelter below" (Nicolson 2003: 120).

218. Chan eil fèill no faidhir air nach faighear Maol Ruainidh, "There's no holiday nor fair but Mulrony will be there"46 (Nicolson 2003: 124).

219. Chan ionann iùl do dhithis no slighe do thriùir, "Two men will take diverse roads, and three will go different ways" (Nicolson 2003: 132).

220. Chan ionann sgeul a' dol don bhaile mhòr 's a' tighinn dachaigh, "It's a different story, going to town and coming back" (Nicolson 2003: 132).

\footnotetext{
${ }^{42}$ When you are in Rome, do as Romans do. (Eng.)

${ }^{43}$ Their visits were prolonged till next morning.

${ }_{44}^{44}$ An expression of hospitality in reference to a guest.

${ }^{45}$ A very hospitable saying.

${ }^{46}$ A silly woman who frequents fairs too much.
} 
221. Chan ionann togradh do dhuine, a' dol a dh'iarraidh mnatha 's ga cur dhachaigh, "Very different is a man's desire, going for his wife and sending her home" (Nicolson 2003: 132).

222. Duine còir an rathaid mhòir 's bèist mhòr a-staigh, "A fine man abroad, and a great beast at home" (Nicolson 2003: 190).

223. Easgaidh mun rathad mhòr seach a dhoras fhèin, "More quick to show the high road than his own door" (Nicolson 2003: 192).

224. Euchdach a-muigh, is brèineach a-staigh, "Distinguished abroad, disgusting at home" (Nicolson 2003: 193).

225. Fada bhon $t$-sùil, fada bhon chridhe, "Far from the eye, far from the heart" (Nicolson 2003: 194).

226. Fàg cuid dithis a' feitheamh an fhir a bhios a-muigh, "Leave the share of two for him that is away" (Nicolson 2003: 195).

227. Faodaidh sinn eag a chur san ursainn, "We may cut a notch in the doorpost" ${ }^{\text {"47 }}$ (Nicolson 2003: 198).

228. Faoileag an droch chladaich, "The seagull of a bad shore" 48 (Nicolson 2003: 198).

229. Furain an t-aoigh a thig, greas an t-aoigh tha falbh, "Welcome the coming, speed the parting guest" (Nicolson 2003: 209).

230. Gach olc an toin a' choimhich, "Let the blame of every ill be on the stranger" (Nicolson 2003: 212).

231. Ged is e 'n taigh, chan e mhuinntir, "Though it be the house, these are not its people" ${ }^{49}$ (Nicolson 2003: 223).

232. Ged is fhad' a-mach Barraigh, ruigear e, "Though Barra be far out, it can be reached" (Nicolson 2003: 223).

233. Gheibh rìg feachd, 's gheibh domhan daoine, "Kings will find armies, and the world men" (Nicolson 2003: 227).

234. Is anfhann a thig, 's làidir a thèid, "Weak they come, and strong depart" ${ }^{\prime 50}$ (Nicolson 2003: 237).

235. Is aobhach duine an taice ri chuid, "A man is cheerful near his own" (Nicolson 2003: 241).

236. Is binn gach ian 'n a dhoire fhéin "Sweet sings each bird in his own grove" ${ }^{, 11}$ (MacGillivray: 15).

237. Is diombuan gach cas air tìr gun eòlas, "Fleeting is the foot in a strange land" (Nicolson 2003: 253).

\footnotetext{
${ }^{47}$ Said on occasion of a long expected or unexpected visit - marking the day with a white stone.

${ }^{48}$ Applied to poor creatures still preferring their wretched home.

${ }^{49}$ Said when an old house is tenanted by new people, a common thing in the Highlands.

${ }^{50}$ Refers to infants.

${ }^{51}$ There's no place like home.
} 
238. Is e miann na lach an loch air nach bi i, "The duck's desire is the water where she's not" (Nicolson 2003: 260).

239. Is èasgaidh an droch ghille air chuairt, "The bad servant is brisk abroad" (Nicolson 2003: 261).

240. Is éigin dol far am bi 'n fhoid, "One must go where his grave awaits him" (MacGillivray: 8).

241. Is fada cobhair o mhnaoi 's a muinntir an Eirinn, "Far is aid from her whose folk are in Ireland" (Nicolson 2003: 263).

242. Is fhada Dùn Eideann bhon fhear tha 'g èirigh san Stòr, "Edinburgh is far from the man who rises at Stoer"

243. Is fheàirrd' an luch sàmhchair, mar a thuirt luch a' mhonaidh ri luch a' bhaile, "The mouse is the better of quietness, as the moor-mouse said to the town-mouse" (Nicolson 2003: 265).

244. Is fheàrr coimhearsnach am fagas na bràthair fad'o làimh, "Better a neighbour at hand than a brother far away" (Nicolson 2003: 273).

245. Is fheàrr coimhearsnach math sa bhaile seo na caraid anns a' bhail' $u d$ thall, "Better a good neighbour in this town than a kinsman in yon town"53 (Nicolson 2003: 273).

246. Is fhurasd' a chur a-mach, fear gun an teach aige fhèin, "Tis easy to put out a man whose own the house is not" ${ }^{\prime 54}$ (Nicolson 2003: 281).

247. Is fhusa duine chumail a-muigh na chur a-mach nuair thig e staigh, "It's easier to keep a man out than to put him out when in" (Nicolson 2003: 282).

248. Is gorm na cnuic the fada uainn, "Green are the hills that are far from us" $" 55$ (Nicolson 2003: 285).

249. Is ioma rud a thachras ris an fhear a bhios a-muigh, "Many things happen to him who goes abroad" (Nicolson 2003: 290).

250. Is làidir a thèid, is anfhann a thig, "Strong they go, and weak return" (Nicolson 2003: 292).

251. Is miann le triubhas a bhith measg aodaich, is miann leam fhèin a bhith measg mo dhaoine, "Trews like to be among clothes; I like to be among my people" (Nicolson 2003: 308).

252. Is treasa dithis san àtha gun bhith fada bho chèile, "Two crossing the ford are best near each other" (Nicolson 2003: 322).

\footnotetext{
${ }^{52}$ Stoer is a parish in the west of Sutherland.

${ }^{53}$ Eun amezek mad (math) a zo gwell, evit na e kerent (na caraid) a-bell (Bret.). God nabo er bedre end Broder $i$ anden By (Dan.). E meglio un prossimo vicino che un lontano cugino (Ital.).

${ }^{54}$ Referring to the ejection of poor tenants in the Highlands.

${ }^{55}$ The distant is most admired, and green grass was considered the best thing that could be on a hill. Is glas iad na conic i bhfad uainn (Ir.).
} 
253. Is uasal a bhith 'nad shuidhe, 'nad ruith, "It's noble to be sitting and running" ${ }^{96}$ (Nicolson 2003: 328).

254. Itheam, òlam, caidileam, "Let me eat, let me drink, let me sleep" (Nicolson 2003: 329).

255. Leig do cheann far am faigh thus a mhadainn e, "Lay your head where you'll find it in the morning" (Nicolson 2003: 334).

256. Ma bheir thu Muile dhiom, cha toir thu muir is tìr dhiom, "You may take Mull from me, but you can't take sea and land from me" (Nicolson 2003: 338).

257. Mar a bha gille mòr nam bram - chan fhuirich e thall no bhos, "Like the great windy lad - he won't stay there or here" (Nicolson 2003: 346).

258. Mo chuid fhèin, mo bhean fhèin is 'Tiugainn dachaigh,' trì faclan as blaisde th' ann (Na trì rudan as milse th' ann - mo chuid fhèin...), "My own property, my own wife and 'Come home,' three of the sweetest of words" (Nicolson 2003: 354).

259. Mòr a-muigh, 's beag a-staigh, "Great abroad, small at home" (Nicolson 2003: 356).

260. Na toir bò à Paibil, 's na toir bean à Boighreigh, "Don't take a cow from Paible, or a wife from Borerary"57 (Nicolson 2003: 369).

261. Olc mun fhàrdaich, is math mun rathad mhòr, "Bad at home, good abroad" (Nicolson 2003: 374).

262. Suirghe air na h-aonaichean, is pòsadh aig a' bhaile, "Wooing o'er the moor, and marrying at home" (Nicolson 2003: 392).

263. Suirghe fada bhon taigh, 's pòsadh am bun an dorais, "Courting far from home, and marrying next door" (Nicolson 2003: 392).

264. Thiginn gu d'choimhead ged bhiodh tu a' còmhnaidh an còs creige, "I would come to see you, though you lived in a rock-cave" (Nicolson 2003: 409).

265. Thoir bean à Ifrinn, 's bheir $i$ dha taigh fhèin thu (bheir $i$ rithist ann thu), "If you take a wife from Hell, she'll take you home with her (she'll bring you back there)" (Nicolson 2003: 410).

266. Treubhach a-muigh agus meadhrach a-staigh, "Brave abroad and cheery at home" (Nicolson 2003: 414). ${ }^{58}$

\footnotetext{
${ }^{56}$ Said of driving in a carriage.

${ }^{57}$ Paible is a farm and village in North Uist, Borerary another island near it.

${ }^{58}$ The Highland type of a man of the right sort.
} 